\title{
THE ECONOMIC UPTURN OF TURKEY UNDER THE AK PARTY's GOVERNANCE
}

Hakan ÖZKAN ${ }^{1}$

Başvuru Tarihi: 25.09.2014

Kabul Tarihi: 15.10 .2014

\begin{abstract}
Comprehensive economic reforms have been conducted since the Adalet ve Kalkinma Partisi Party (AK Party) came to power. In particular, the reform program accepted in 2002 accelerated Turkey's existing policy of opening the country to outside world. The AK Party relied on the Customs Union Agreement with the European Union (EU), which was enforced in 1996 as an important condition for a successful export strategy. Within the framework of the government's studies, visible changes occurred in the economy. In May 2003, inflation regressed and economic growth of 5.9\% was realised. The AK Party continued this slight growth through the IMF programme, which continuously regressed inflation.
\end{abstract}

Keywords: Turkey, AK Party, Economy, EU

Jel Codes: E20, F50

\section{AK PARTI YÖNETIMI ALTINDA TÜRKIYYE'NIN EKONOMIK YÜKSELİşİ}

ÖZ

AK Parti yönetime geldiğinden bu yana kapsamlı ekonomik reformlar yürütüldü ve özellikle 2002 yllinda kabul edilen reform programı, Türkiye'nin zaten var olan güçlü dışa açılımına yeni bir ivme kazandırdı. Burada Ak Parti, başarll bir ihracat stratejisi için önemli bir koşul olarak 1996 yllında yürürlüğe giren AB ile Gümrük Birliği Antlaşması'na bel bağlamaktadır. Hükümet çalışmaları çerçevesinde, ekonomide görünür değişimler oldu. 2003 mayls ayında enflasyon geriledi ve \%5,9 ekonomik büyüme kaydedildi. AK-Parti bu hafif yükselişi, enflasyonu sürekli gerileten IMF programlartyla sürdürdü.

Anahtar Kelimeler: Türkiye, AK-Parti, Ekonomi, AB

Jel Kodlar1: E20, F50

\footnotetext{
${ }^{1}$ Yrd. Doç. Dr., Karabük Üniversitesi, iiBF, hakanozkan@karabuk.edu.tr
} 


\section{INTRODUCTION}

Although the financial crisis of 2001 hit Turkey, financial reforms as a part of the IMF program and the country's new export strategy for the booming automobile and electronics sectors facilitated Turkey's economic growth by approximately 6\% annually until 2008. During this period, the industry and service sectors were very important to Turkey's economy; however, the traditional agriculture sector which accounted for approximately over $25 \%$ of the country’s employment remained a problem.

Global economic conditions and tighter fiscal policy caused GDP to contract in 2009; however, Turkey’s well-regulated financial markets and banking system helped the country withstand the global financial crisis and GDP rebounded strongly to $8.2 \%$ in 2010 as exports returned to normal levels following the recession. Further, economic and judicial reforms and the prospective European Union (EU) membership are expected to boost Turkey's attractiveness to foreign investors. (CIA Factbook, 2014)

The EU crisis has negatively affected Turkish-European relations because the crisis gave greater prominence to the economic bottleneck within the EU and focused on the financial problems of Greece and Cyprus. The economic crisis in the EU also gave the Turkish government under Tayyip Erdoğan the option to withdraw unilaterally from the negotiations. In all cases, the descriptive statistics play into the hands of Turkey. Stable growth rates and the country's geopolitical position with the adjacent future markets of Russia and the Arab countries are not to be underestimated.

Even if the negotiations with the EU do not achieve their desired goal, Turkey’s internal aim of becoming one of the top 10 economies of the world is still plausible. Except for Poland, no comparable country has similar stable indicators and such a bright outlook for the upcoming decade. ("Anchors aweigh', 2010)

Turkey is a vocal member of the Group of Twenty (G20), a group of major economies of the world. It held a temporary seat in the United Nations Security Council in 2009-2010 and knocking at the BRICs (emerging economic giants namely Brazil, Russia, India and China) door. Some forecasts suggest that Turkey, except for India and China, will grow faster during the next decade than any other country. Others predict that Turkey could become the world's tenth largest economy by 2050. ('Anchors aweigh', 2010) This is partly because of the country's favourable demographic outlook. The average age of its 77 million citizens is only 29 years, compared with the EU, where it is above 40 years. By 2050, Turkey's population will have grown to almost 100 million. By then, if Turkey has managed to get into the EU, it will be its most populous member, far ahead of Germany with a population of only 70 million.

However, the GDP depends on factors other than population as well. Therefore, this paper identifies these factors. Furthermore, an overview of the economic data and historical and current developments is provided. 


\section{ECONOMICAL OVERVIEW TILL 2002}

From 1945 to the 1980s, Turkey faced heavy crises, which seemed to be the cause of social and political revolutions. From the 1980s, economic reforms led to the liberalisation of the country's capital markets. Interestingly, Islamic nations in particular and the so-called 'alien worker' supported the Turkish Republic (Joppien, 2011:47). This first step towards modernisation enabled the flexibility needed among small-and medium-sized enterprises. The effect was a structural change away from an economy dominated by large firms (Hoffmann, 2003:27). In this context, the foundation of the independent businessmen's association, Müstakil Sanayicileri ve Iş Adamları Derneği (MÜSIAD) (Schuß, 2008:359), must be mentioned as representing a counterpart to the Türk Sanayicileri ve Işadamları Derneği (TÜSIAD) (Joppien, 2011:49).

Nevertheless, the liberalisation of the capital market also had a downside as shown by the incidents that occurred around the turn of the millennium. As a result of the global crisis, the increasing debts and massive corruption among banks, the government was forced to admit that the Turkish Republic faces one of the largest crisis in its history. The effect was that foreign investors discounted almost all of their money whereby the Turkish Lira fell to an all-time low. A loan from IMF combined with extensive reforms saved the Turkish Republic from bankruptcy (Bal \& Onay-Ok, 2010:113).

This period precisely marked the beginning of the successful emergence of a new political party, the Adalet ve Kalkınma Partisi (AK Party), which promised reforms and wealth.

\section{THE AK PARTY AS THE MOTOR OF EXPANSION}

The 2001 elected AK Party faced a disastrous situation that forced the new government to engage in widespread economic reforms. Under Kemal Derviş, Minister of State for Economic Affairs, the already foreign trade-orientated economy received another impetus. However, even though the past was not bright, Derviş based his activities on the 1996 customs union agreement with the EU (Yilmaz, 2004:63). Derviş used his independence from domestic vested interests and the support of domestic reformers and civil society to push through a difficult stabilisation programme with far-reaching structural changes and sweeping bank reforms that protected state banks from political use.

Moreover, Derviş strengthened the central bank's independence and pushed through deep structural reforms in agriculture, energy and the budget process. These reforms, his reputation and toplevel contacts in the U.S. and Europe, helped him mobilise \$20 billion in new loans from IMF and the World Bank ('Derviş says Turkey has major role to play in EU', 2012). Furthermore, the balance could be stabilised through a rigid austerity policy and successful privatisations that had another positive effect on the Turkish economy—halting the decline in the inflation rate (Yilmaz, 2004:63). 
Hence, a logical step was that foreign investors' trust in the governing AK Party continued to increase. In such a manner, financially provided enterprises began to expand, particularly in the fields of textiles, electronics, commodities and vehicle manufacturing (Yilmaz, 2004:63). From this viewpoint, the fact that corporate income taxes for enterprises and income taxes for individuals were reduced does not appear insignificant (Yilmazoglu, 2008:55). Moreover, an upward trend was seen to occur from an economy dominated by agriculture towards a more service-orientated economy under the AK Party's governance, which enables the statement to be made that no significant difference exists between western nations and the Turkish Republic (Senkyr, 2010:88).

Apart from reforms that directly influence the economy, the AK Party took further steps, primarily in the social and societal fields. Essentially, women's rights, freedom of press and speech were strengthened (Joppien, 2011:132). These basic characteristics of democratic countries seem to have a further albeit indirect effect on the success of the Republic of Turkey.

In summary, the Turkish Republic under the AK Party received new economic stability and a dynamic face that is detailed in the following sections.

\section{ECONOMIC DEVELOPMENT FROM 2002 TILL 2012}

Observing the development of the most important economic indicators-GDP, the inflation rate and the unemployment rate-during the past 10 years clearly indicates that under the AK Party's governance, the Republic of Turkey experienced a very stable economy (Figure 1). In particular, the rapidly decreasing inflation rate (percent change) from 2002 to 2004 demonstrates the successful efforts of the group around Prime Minister Recep Tayyip Erdoğan (Figure 1).

Moreover, even the 2008 global financial crisis could not sustainably stop the boom of the Turkish economy, which is impressive. Although international problems also affected Turkey, the nation recovered within two years. Only in 2009 did the country's inhabitants have to deal with a negative percent change in GDP (Figure 1). Concerning the connection between the inflation rate and the unemployment rate, 2009 appears to provide additional support for the Phillips curve, which simply indicates that in the short term, a lower unemployment results in a higher inflation rate (Figure 1). 
Figure 1: Development of main economic indicators from 2002 to 2012.

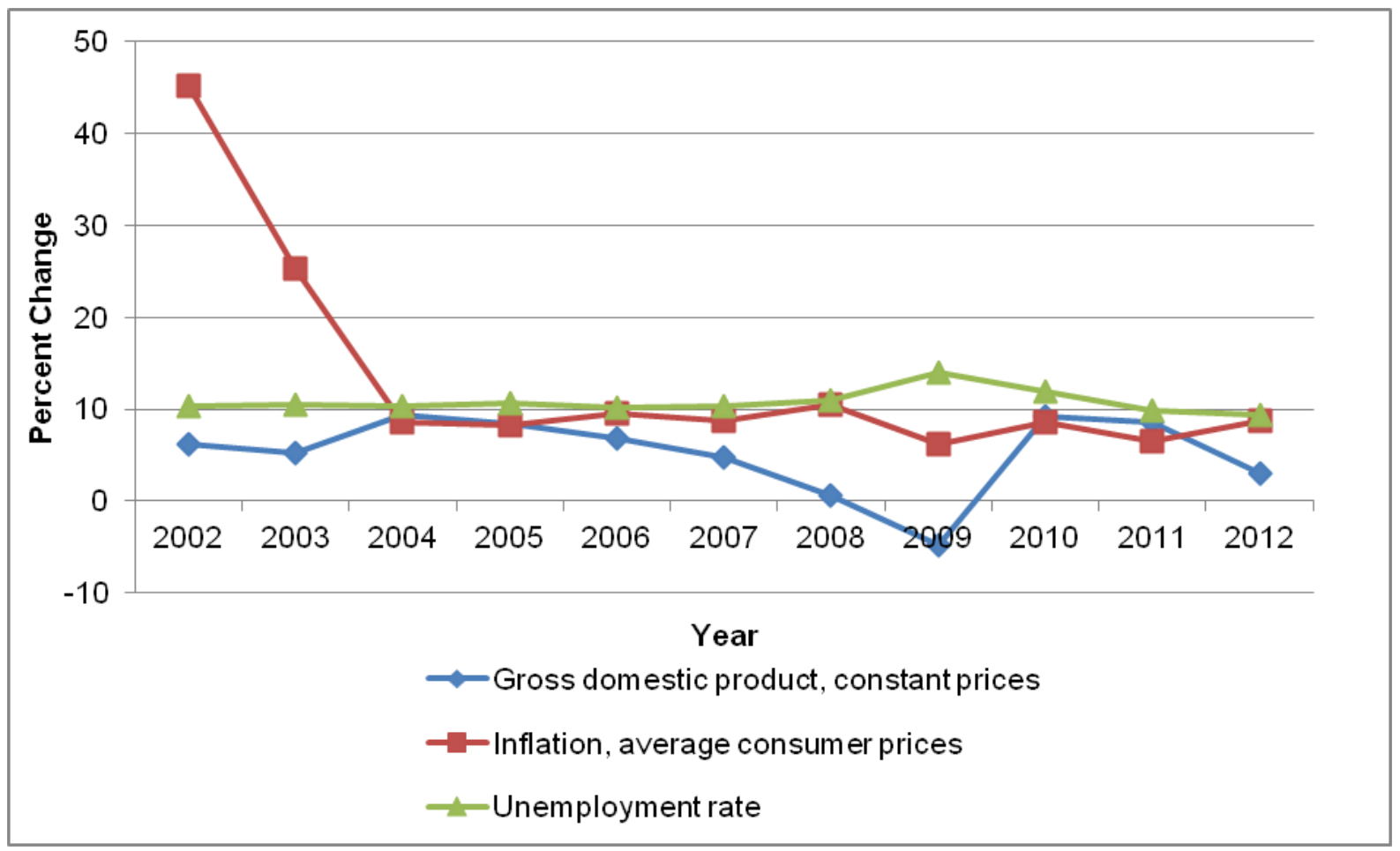

Source: Own diagram based on IMF data downloaded from www.imf.org.

Two additional indicators are the percent changes in the volume of imports and exports of goods and services during the global crisis. During the disastrous years of 2008 and 2009, Turkey achieved a higher exports rate than an imports rate (Figure 2).

The visible improvements in the Turkish economy have also boosted foreign trade, with exports reaching USD135 billion by the end of 2011, up from USD36 billion in 2002. Similarly, tourism revenues, which were approximately USD8.5 billion in 2002, exceeded USD23 billion in 2011 ('Economic outlook', N.D.). Significant improvements in such a short period registered Turkey on the world economic scale as an exceptional emerging economy, the 16th largest economy in the world and the fifth largest economy when compared with the EU countries. Although many economies have been unable to recover from the recent global financial recession, the Turkish economy expanded by $9.2 \%$ in 2010 and 8.5\% in 2011, thus standing out as the fastest growing economy in Europe and one of the fastest growing economies in the world (“Economic outlook,” N.D.). Compared with the 1990s, the economic growth in Turkey is a sign of successive continuity in the Turkish economy and a guarantee of stabilisation of the political situation, which in turn initiates an increase in wealth within the country. Widespread 
international relations at social and state levels will continue to promote the economic growth of Turkey over the long term, thus increasing the welfare of broad social layers.

Figure 2: Annual percent change of imports and exports from 2002 to 2012.

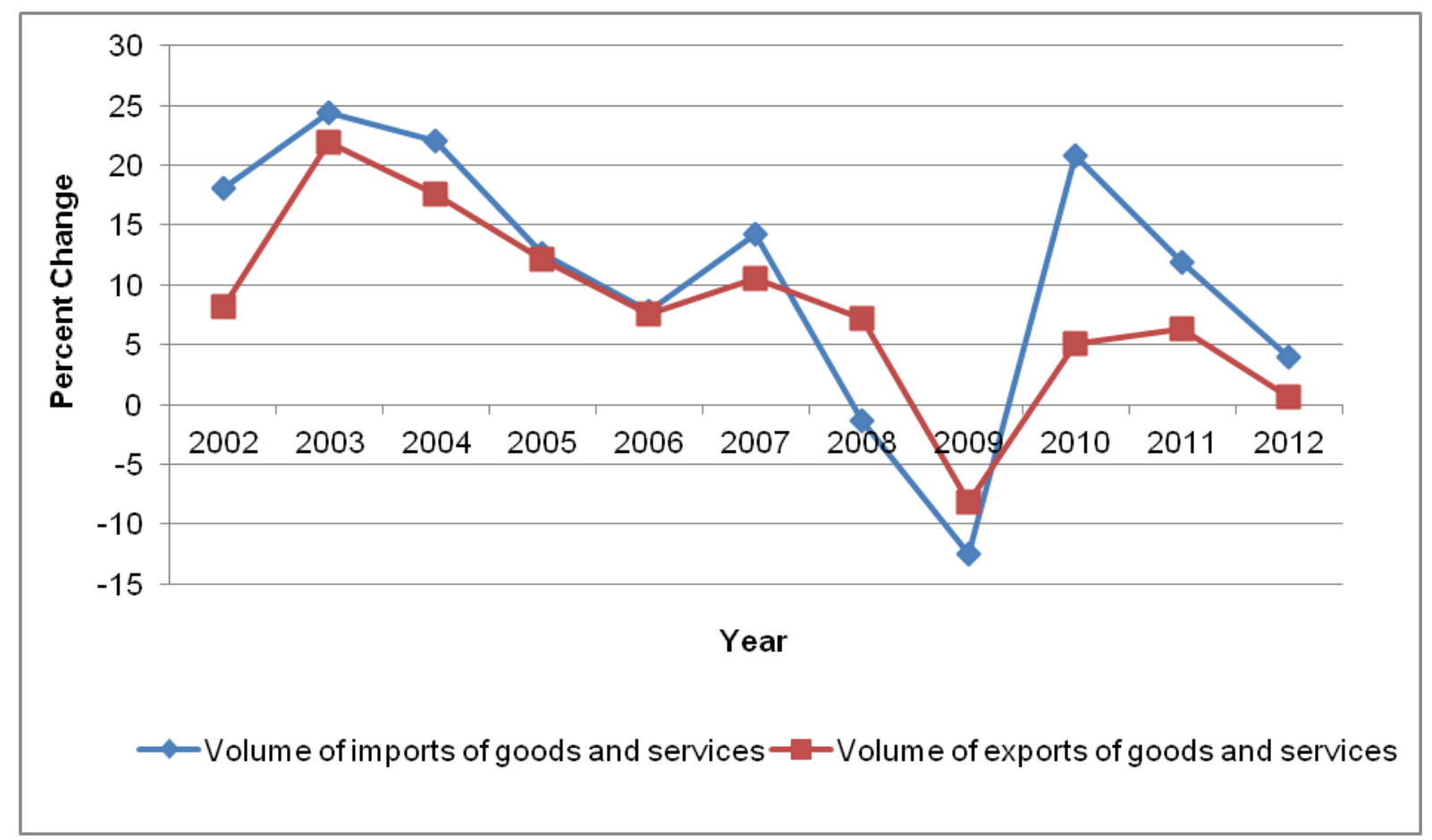

Source: Own diagram based on IMF data downloaded from www.imf.org.

Finally, the focus is directed towards the development of the net debt of the general government. As illustrated in Figure 3, a reduction in net debt from $70 \%$ to less than $30 \%$ of the GDP provides another illustration of the Turkish government's pursuit of implementing economic reforms.

Hence, since 2004 Turkey has been meeting the ‘60\% EU Maastricht criteria’ for public debt stock. Similarly, during 2002-2011, the budget deficit decreased from more than $10 \%$ to less than 3\%, one of the EU Maastricht's criteria for balancing the budget. Because the country's GDP levels more than tripled to USD772 billion in 2011 from USD231 billion in 2002, GDP per capita soared to USD10, 444 from USD3, 500 in the given period ('Economic outlook', N.D.). 
Figure 3: Development of the general government’s net debt from 2002 to 2012.

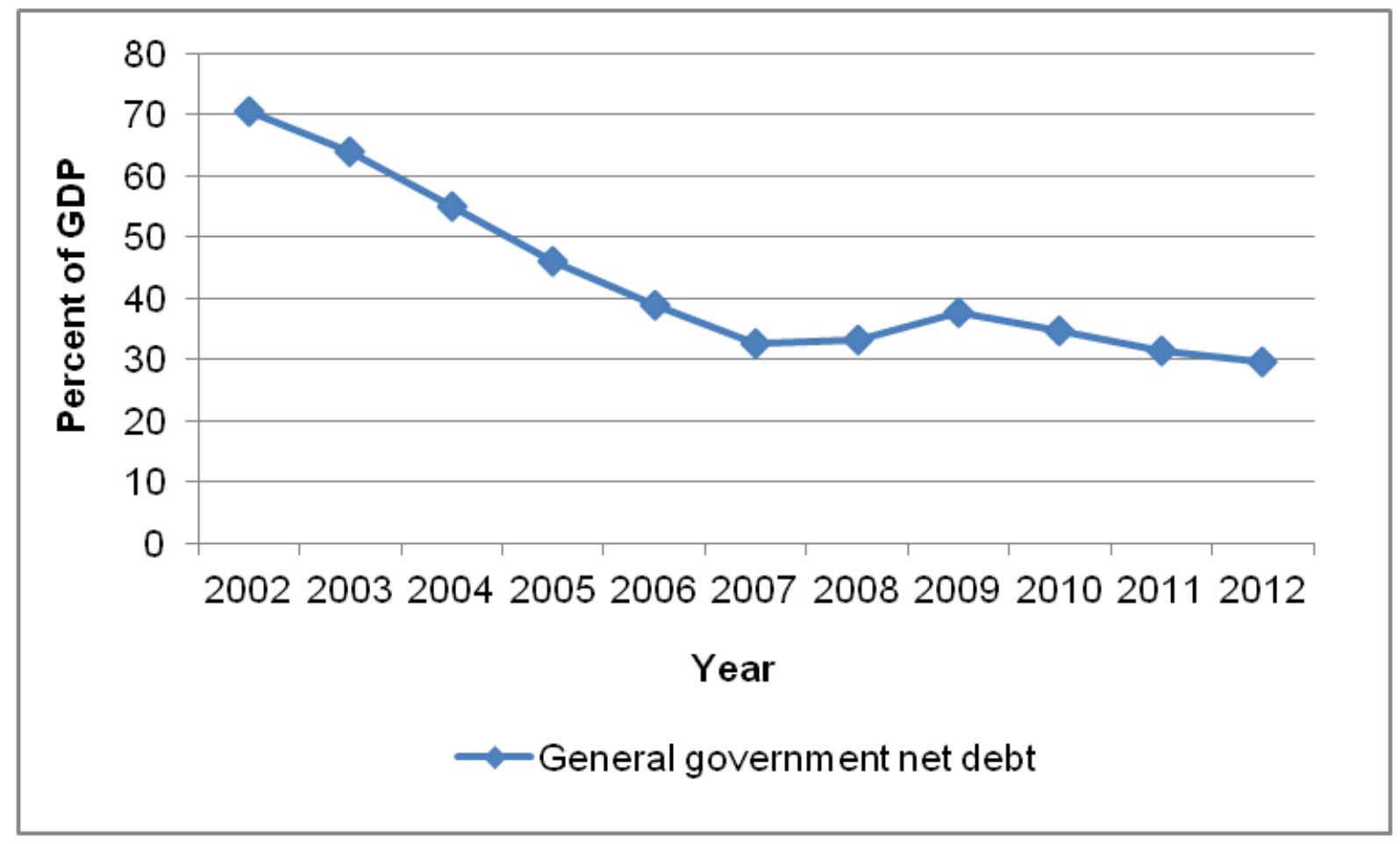

Source: Own diagram based on IMF data downloaded from www.imf.org.

\subsection{COMPARISON WITH SELECTED COUNTRIES}

The appearance that the Turkish economy is in a good condition is not deceptive; however, too much focus on the isolated numbers obstructs the general view. Only a comparison with other countries allows for a substantive assessment.

Figure 4 precisely indicates that from 2003 the annual percent change in the GDP of Spain and Greece was much lower than that of Turkey. Although the percent changes in GDP during the years before the international finance crisis were similar, Turkey demonstrated its economic power after the crisis. 
Figure 4: Comparison of annual percent change in the GDP of Greece, Spain and Turkey from 2002 to 2012.

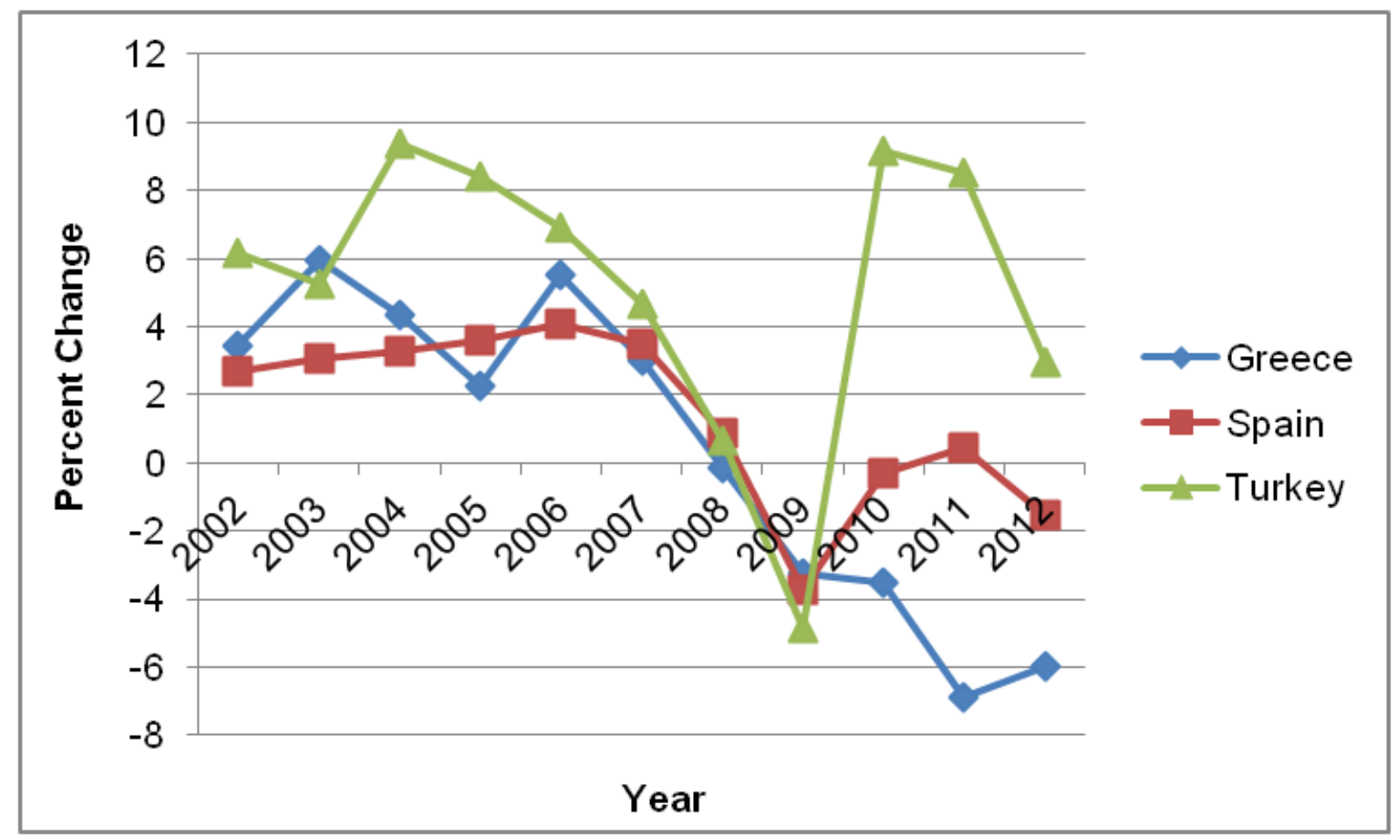

Source: Own diagram based on data from the IMF downloaded from www.imf.org.

When Turkey's competitiveness is compared with 12 countries that recently joined the EU, the country is viewed as having more advanced business sophistication, innovation and institutional infrastructure in public industries and better performance in institutional governance in the private sector, but worse intellectual property rights, railway network quality, port quality and prevalence of information and communications technology (ICT) (Republic of Turkey, Ministry of Industry and Trade, 2010:33).

In other areas, Turkey and other countries demonstrate almost equal performance. Therefore, Turkey has the competitive edge in a broad region covering the Middle East, the Caucasus, North Africa and the Balkans (Republic of Turkey, Ministry of Industry and Trade, 2010:33). From an economic perspective, Turkey has millions of consumers and its economy continues to grow each year, whereas the rest of Europe is fighting to recover from the crisis. Turkey's booming tourism sector contributes its share to the country's positive economic development.

5 RESOURCES AND ECONOMIC SECTORS 


\subsection{NATURAL RESOURCES}

Although the Republic of Turkey has several natural resources, it is not a significant player like many countries in the Middle East. However, its geostrategic position between traditional oil producing countries and the so-called western world is more important than the resources itself. In addition to oil and gas, following other sources will continue to exist.

Minerals: According to the CIA World Factbook, Turkey is among the top 10 producers of minerals in the world in terms of diversity and produces more than 60 different minerals. For example, Turkey's boron salt reserves constitute $72 \%$ of the world's total reserves ("CIA World Factbook,” N.D.).

Petroleum and gas: Although Turkey is an oil and natural gas producer, its production level is inadequate for self-sufficiency, making the country a net importer of both oil and gas. Nevertheless, the recent discovery of new oil and natural gas fields in the country will help Turkey achieve greater self-sufficiency in energy production (Inogate, N.D.).

Several gas pipeline projects and the Baku-Tbilisi-Ceyhan pipeline facilitate the transport of central Asian gas to Europe through Turkey, which over the long term will help address Turkey's dependence on imported oil and gas to meet $97 \%$ of its own energy needs (“CIA World Factbook,” N.D.).

Nuclear energy: To cover the increasing energy needs of its population and to ensure a continued improvement in living standards, Turkey plans to build several nuclear power plants. Following the construction of experimental reactors, proposals to build large-scale nuclear power plants were presented as early as the 1950s by Turkish Atomic Energy Authority (TAEK); however, the plans were repeatedly cancelled even after bids were made by interested manufacturers because of high costs and safety concerns ('Anchors aweigh,' 2010).

\subsection{MAIN SECTORS}

Traditionally, the economy is separated into three sectors: agriculture, industry and the service sector. The following chapter provides a brief overview of the importance of the specific sectors for the Republic of Turkey.

\subsubsection{AGRICULTURAL SECTOR}


Turkey’s large agricultural sector employed 29.5\% of its citizens in 2009. Traditionally, Turkey's farmers have been fairly fragmented with $85 \%$ of agricultural holdings on less than 10 hectares and 57\% of these being fragmented into four or more non-contiguous plots. Many old agricultural attitudes remain widespread; however, these traditions are expected to change through the EU accession process (Ray \& Gül, 1999:361).

Turkey has been self-sufficient in food production since the 1980s. During 1989, the country's total wheat production was 16.2 million tonnes, and its barley production was 3.44 million tonnes. The country's agricultural output has been growing at a satisfactory rate. However, since the 1980s, agriculture has been declining in terms of its share in the total economy (Food and Agricultural Organization [FAO], N.D.).

The government has also initiated many planned projects, such as the Southeastern Anatolia Project (G.A.P. project). The program includes 22 dams, 19 hydraulic power plants and the irrigation of 1.82 million hectares of land. The total cost of the project is estimated at \$32 billion (Ünver, 1997:453).

\subsubsection{INDUSTRIAL SECTOR}

Recently, many multinational companies, primarily based in the EU have chosen Turkey as their production and investment base. Reinforcing this trend in line with correct strategies will contribute to the competitiveness of both Turkey and the EU. In terms of the subsectors of the Turkish manufacturing industry, a substantial qualitative transformation occurred between 1996 and 2008 (Republic of Turkey, Ministry of Industry and Trade, 2010:34).

The share of automotive, machinery, white good, electronic, petroleum and rubberplastic products in the total manufacturing industry rose considerably. In contrast, the share of garments, textile products and food decreased from 1996 to 2008. Especially, as a result of international pressure from India and China, the share of traditional labour-intensive industries declined within exports as a whole because these industries were compelled to switch to industries with higher value added and greater innovative production structures. Furthermore, changes in commodity prices are expected to affect the export and production structure of the Turkish manufacturing industry (Republic of Turkey, Ministry of Industry and Trade, 2010:34).

\subsubsection{SERVICE SECTOR}

In parallel with the positive industry and GDP developments in Turkey in recent years, the country has started to increasingly become a paradise for the service industry. In fact, new investments made in service sectors such as retailing, air transportation, finance, health, tourism 
and education have been successful initiatives and are good examples for other entrepreneurs to gain an interest in the service sector ('Turkey: A country with new horizons', 2012).

During the past five years, the share of the service sector in Turkey's GDP increased from $58.5 \%$ to $61.7 \%$. This increase is interpreted as a good sign for Turkey because the accepted notion is that as a country becomes more developed, the service sector's share in the country's GDP increases. Turkey is considered as being two points away from achieving the average global level based on this perspective ('Turkey: A country with new horizons’, 2012).

\subsection{SECTOR COMPETITIVENESS}

Concerning the competitiveness of the Turkish economy from a global perspective, a brief overview indicates that several companies and enterprises, particularly bank institutes, telecommunication enterprises and conglomerates, belong to the Top 1000 World Banks (Table 1). This external evaluation comprises a mix of sales, profits, assets and market value.

Table 1: Largest Turkish companies 2012.

$\begin{array}{lcccccc}\text { Company } & \text { Rank } & \text { Sales } & \text { Profits } & \text { Assets Market Value } \\ \text { Garanti Bank } & 359 & 9.2 & 2.0 & 86.7 & 16.1 & \\ \text { Koc Holding } & 370 & 40.2 & 1.1 & 52.0 & 9.7 & \\ \text { Isbank 425 } & 11.1 & 1.4 & 97.6 & 10.8 & & \\ \text { Sabanci Holding } & 446 & 12.7 & 1.1 & 84.3 & 9.7 \\ \text { Akbank } & 470 & 6.4 & 1.3 & 74.0 & 16.4 & \\ \text { Halkbank } & 657 & 5.5 & 1.2 & 48.9 & 8.9 & \\ \text { Turk Telekom } 864 & 6.3 & 1.1 & 8.4 & 15.0 & \\ \text { Vakif Bank } & 953 & 4.4 & 0.8 & 49.5 & 4.8\end{array}$

Source: Chen, L. \& Murphy, A. (Eds.) (2014). The world' s biggest companies. Forbes Magazine. Retrieved from http://www.forbes.com/global2000/\#p_1_s_a0_All\%20industries_Turkey_All\%20states_ 
Although other fields in the Turkish economy are not as competitive as the previous examples, including primarily petrol, automobiles and vehicles, electrical machines and metal products, the outlook is bright (Figure 5). However, the change from an agricultural towards an industry- and service-affected economy takes its toll: traditional areas such as the textile industry (including garments) and fruits become less important. In particular, in the future, less developed economies in which simple standardisation of handicrafts plays a decisive role will replace the Republic of Turkey in such industries.

Figure 5: Sector competitiveness: Shares in the world and growth ratios, 2006.

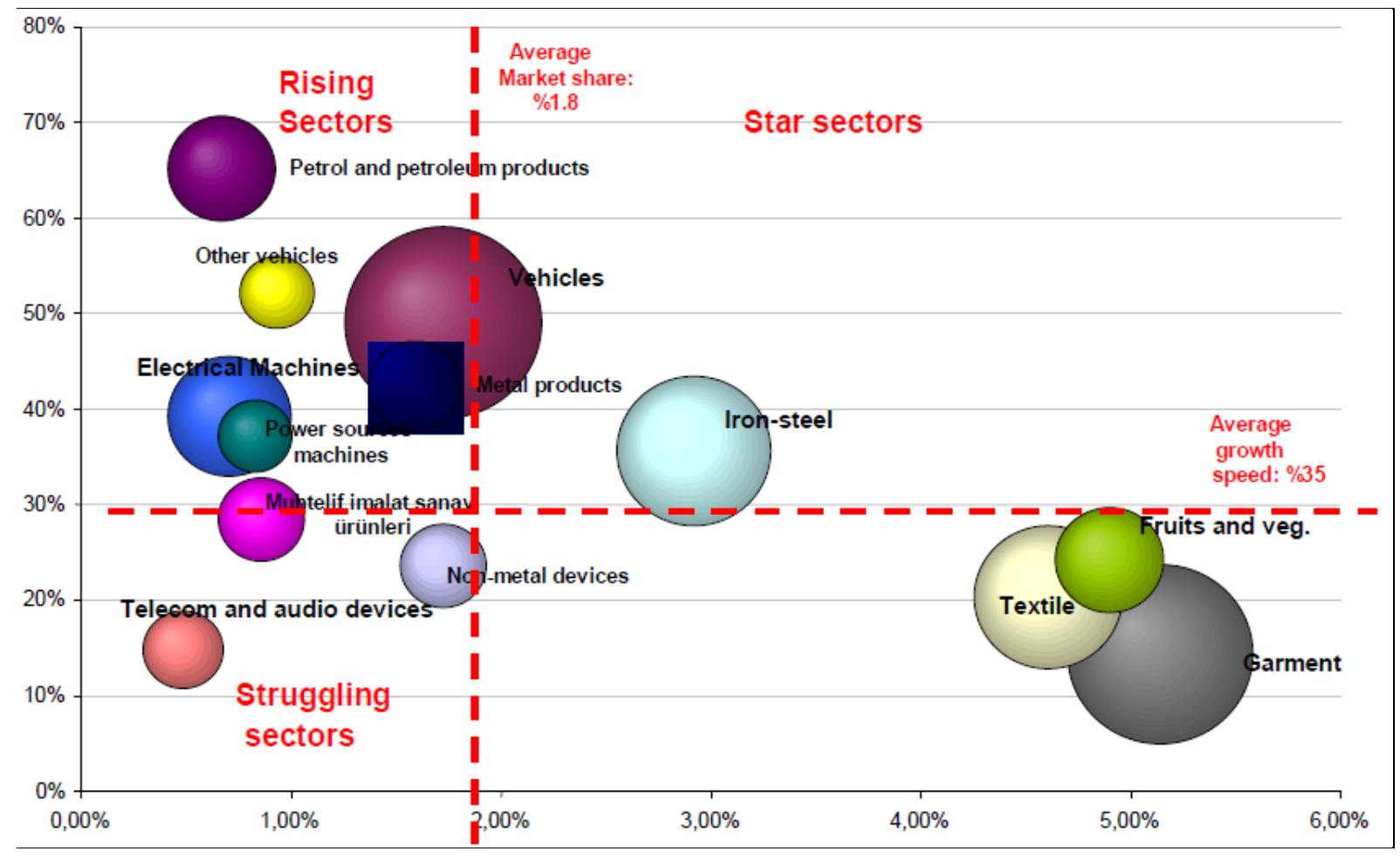

Source: Republic of Turkey, Ministry of Industry and Trade, 2010:35.

\section{ECONOMIC OUTLOOK}

In the short run, the high current account deficit is a reason for concern. Inflationary pressures may intensify if oil prices remain elevated. A favourable employment scenario in Turkey will likely support income growth and benefit overall domestic demand. If external demand improves, the Turkish export sector will expand. Therefore, although the momentum is expected to gradually fade away, the economy is likely to grow at a healthy rate (Figure 6). 
Figure 6: Long-term annual average real GDP growth (\%) forecast in OECD countries from 2011 to 2017.

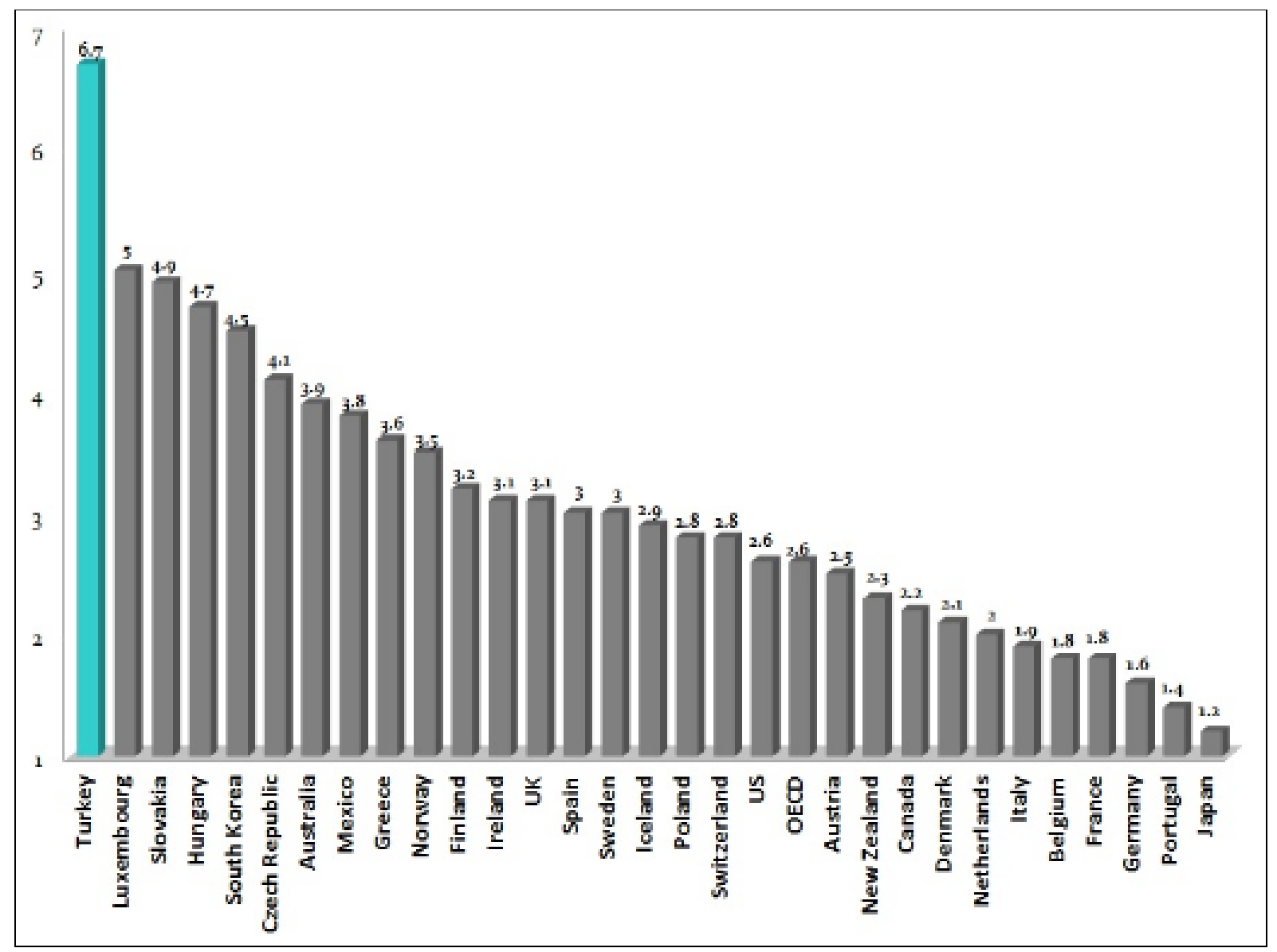

Source: The Republic of Turkey Prime Ministry Investment Support and Promotion Agency (N.D.). Economic outlook. Retrieved from http://www.invest.gov.tr/enus/turkey/factsandfigures/pages/economy.aspx

Although the EU is still important to Turkey's exports, the share of other regions is increasing. In 2007, exports to the EU27 countries, valued at $\$ 60.3$ billion, comprised $56.3 \%$ of total exports. This figure declined to $46.9 \%$ in 2009. However, exports to near and Middle Eastern countries, which comprised 19\% of total exports, reached $\$ 19$ billion. Exports to African countries reached $\$ 10.2$ billion, reflecting an increase of 12.3\% (Republic of Turkey, Ministry of Industry and Trade, 2010:33.).

Despite its increasing effect on Europe, Turkey’s accession into the Eurozone seems unlikely in the near future. Turkey has transitioned from being a predominantly agrarian to a market-driven economy that is open to international trade and financial services. Furthermore, 
Turkey has the potential to serve as a link between Europe and Asia for trade and strategic oil and gas pipelines (Burli, 2011).

\section{CONCLUSION}

Because Europe faces a demographic disadvantage from its dwindling working population, Turkey's young population could be an important source of labour. In contrast, Europe's continuing sovereign debt crisis may further delay Turkey's accession to the EU. Furthermore, the uncertainty of Eurozone stability could deter Turkey. Policymakers may prefer to have an independent monetary policy in the event that an economic downturn in Europe becomes inevitable (Burli, 2011). Nevertheless, the EU members argue that giving Turkey membership into the EU will increase the number of Turkish workers into the labour market—somewhat of an exaggeration. Thus, with respect to southern expansion, the feared rush has failed to materialise because the said states, such as Spain and Portugal, have gained much in terms of prosperity during the few years of their membership despite the economic crisis, and their countries are more attractive.

Finally, Turkey may also benefit by controlling its own exchange rate to protect its competitiveness against other European nations. The Turkish economy expanded for 27 consecutive quarters between 2002 and 2008 from increases in productivity. The country has made significant progress in terms of harmonisation with the EU in economic, social and legislative areas. The wide and diverse manufacturing industry of Turkey, with strong international connections and manufacturing primarily for export, entered a phase of rapid development after 2001. Its stability coalesced with the impact of the customs union agreement with the EU and resulted in a significant transformation in manufacturing and the structure of foreign trade (Republic of Turkey, Ministry of Industry and Trade, 2010:28.). The sustainability of this growth will now be revealed in the coming years. In this respect, the problems that appear are related to high inflation and a large number of unemployed in the total population.

In conclusion, the previous period of the AK Party allowed a successful restructuring of the Turkish economy. Both absolute and relative growth rates suggest that a turnaround has succeeded in transforming Turkey's economy into one with a western character. Contrary to the almost traditional instability that characterised Turkish society in recent decades, the country seems to have normalised at the social level under the AK Party government. 
The three most important factors are the significant positive economic development, which was apparently not infected by the global economic crisis, the liberalisation of society and the concentration of the decisions made by the politically elite leadership.

These three indicators are mutually interrelated because through the economic recovery the leadership gains consent and therefore is able to rely on a broad legitimacy for further necessary reforms. This opening inward releases energy in economic terms, which is expected to have a positive effect on the Turkish economy. 


\section{REFERENCES}

Bal, S., Onay-Ok, A. (2010). Der Beitritt der Türkei zur EU und die Situation der Demokratie, Menschen- und Minderheitenrechte. Norderstedt, Germany: GRIN Verlag.

Burli, P. (2011). 'Turkey: More positive than negative'. Retrieved from http://www.deloitte.com/view/en_GX/global/insights/deloitte-research/economic-research/global-economicoutlook/eca6bef1dc141310VgnVCM3000001c56f00aRCRD.htm.

Forbes Magazine. 'The World's biggest companies'. Retrieved fromhttp://www.forbes.com/global2000/\#p_1_s_a0_All\%20industries_Turkey_All\%20states

Hoffmann, J. (2003). Aufstieg und Wandel des politischen Islam in der Türkei. Berlin: Hans Schiler Verlag.

Joppien, C. (2011). Die türkische Adalet ve Kalkinma Partisi (AK Party)—Eine Untersuchung des Programms Muhafazakar Demokrasi. Berlin: Klaus Schwarz Verlag.

‘Anchors aweigh’ (2010). Retrieved from http://www.economist.com/node/17276440?story_id=17276440.

N.N. 'Derviş says Turkey has major role to play in EU'. Retrieved from http://www.businessturkeytoday.com/economist-dervis-says-turkey-has-major-role-to-play-in-eu.html.

N.N. 'Economic outlook'. Retrieved from http://www.invest.gov.tr/enus/turkey/factsandfigures/pages/economy.aspx.

N.N. 'Turkey: A country with new horizons for the services sector'. Retrieved from http://www.businessturkeytoday.com/turkey-a-country-with-new-horizons-for-the-services-sector.html.

Ray, I., Gül, S. (1999). More from less: policy options and farmers choice under water scarcity. In Irrigation and drainage Systems (p. 361-383). Netherlands: Kluwer Academic Publishers. Retrieved from http://erg.berkeley.edu/publications/Isha\%20Ray/waterscarcity.pdf.

Republic of Turkey, Ministry of Industry and Trade (2010). Turkish industrial strategy document 2011-2014. Retrieved from http://www.sanayi.gov.tr/Files/Documents/TurkiyeSanayiStratejisiIngilizce.pdf.Senkyr, J. (2010). Die Türkei auf dem Weg zur regionalen Mittelmacht. In KAS Auslandsinformationen, 5/2010. Konrad Adenauerstiftung. Retrieved from http://www.kas.de/wf/de/33.19452/ am 11/11/2011.

Ünver, O. (1997). Southeastern Anatolian Project (GAP). In Water Resource Development (p. 453-483).

Yilmaz, M. (2004). Türkei und EU - Die Suche nach einer Partnerschaft. Berlin: Berliner Wissenschaftsverlag.

Yilmazoglu, D. (2008). Investitionsbedingungen für deutsche Unternehmen in der Türkei: Steuern in Vergleich. Norderstedt, Germany: GRIN Verlag.

\section{Internet}

CIA Factbook www.cia.gov

Food and Agriculture Organization www.fao.org

International Monetary Fund www.imf.org 